\title{
PRESCRIBING ANTIPSYCHOTICS IN MONTENEGRO: A FOCUS GROUP ANALYSIS
}

\author{
Ivana Ilickovic ${ }^{1}$, Slobodan M. Jankovic ${ }^{2}$
}

${ }^{1}$ Farmegra Ltd., Podgorica, Montenegro

${ }^{2}$ Faculty of Medical Sciences, University of Kragujevac, Serbia

\author{
PROPISIVANJE ANTIPSIHOTIKA U CRNOJ GORI: \\ ANALIZA FOKUS GRUPE \\ Ivana Iličković ${ }^{1}$, Slobodan Janković ${ }^{2}$ \\ ${ }^{1}$ Farmega Ltd, Podgorica, Crna Gora \\ ${ }^{2}$ Fakultet medicinskih nauka, Univeryitet u Kragujevcu, Srbija
}

\section{ABSTRACT}

Background. Although prescribing antipsychotics to patients with schizophrenia is advised by national and/or international evidence-based practice guidelines, the implementation of the guidelines in clinical practice is still matter of concern.

Objective. The aim of our study was to estimate schizophrenia guideline adherence and identify eventual barriers to its implementation in Montenegro.

Method. This study used focus group methodology. The focus group was composed of two psychiatrists, one psychologist, one pharmacist from a community pharmacy, one pharmacist from the State reimbursement fund, one pharmacist from a drug wholesaler and the chief investigator, a clinical pharmacologist. The focus group took place in Podgorica, Montenegro, in 2013. The analysis of recordings was performed using an iterative, qualitative technique and a constant comparison method.

Results. The most important barriers to the implementation of evidence-based guidelines for the treatment of schizophrenia in Montenegro are non-adherence to medication, low level of psychiatrist-patient concordance, restrictive procedures for prescribing atypical antipsychotics, lack of availability of newer antipsychotics and some dosage forms, and mixing primary, secondary and tertiary care services within a tertiary care psychiatric institution.

Conclusion. Addressing the barriers identified by this focus group and avoiding the consequences of poor adherence would be the first steps for better mental health planning in the community.

Key Words: Schizophrenia, treatment guidelines, nonadherence, concordance.

\section{SAŽETAK}

Uvod. Mada je propisivanje antipsihotika pacijentima sa šizofrenijom regulisano nacionalnim i/ili medunarodnim smernicama dobre kliničke prakse, zasnovanim na dokazima, primena ovih smernica u praksi je daleko od željene.

Cilj. Cilj naše studije je bio da proceni koliko se psihijatri u Crnoj Gori pridržavaju smernica prilikom propisivanja antipsihotika, $i$ da identifikuje eventualne prepreke za njihovu punu primenu.

Metod. U studiji je korišćena matodologija fokus grupe. Fokus grupu su sačinjavali dva psihijatra, jedan psiholog, jedan farmaceut iz vanbolničke apoteke, jedan farmaceut iz Fonda zdravstvenog osiguranja, jedan farmaceut predstavnik veledrogerije i glavni istraživač, klinički farmakolog. Sastanak fokus grupe je održan u Podgorici, Crna Gora, tokom 2013. godine. Analiza fonografskih zapisa sa sastanka je radena iterativnom kvalitativnom tehnikom $i$ metodom stalnog poredenja.

Rezultati. Najvažnije prepreke za punu primenu vodiča za lečenje šizofrenije su ne-pridržavanje propisanoj terapiji, nedovoljno učešće pacijenata u donošenju odluka o njihovom lečenju, komplikovana administrativna procedura za propisivanje atipičnih antipsihotika, nedostupnost novijih antipsihotika $i$ nekih doznih formi, kao i pomešanost primarnih, sekundarnih $i$ tercijernih zdravstvenih usluga u bolnicama namenjenim samo za tercijernu zaštitu.

Conclusion. Obraćanje pažnje na prepreke za primenu smernica koje je identifikovala focus grupa i popravljanje adherence pacijenata su prvi koraci ka boljem planiranju psihijatrijske zdravstvene zaštite u Crnoj Gori.

Ključne reči: Shizofrenija, smernice dobre kliničke prakse, slaba adherenca, učešće pacijenta. 


\section{INTRODUCTION}

Prescribing antipsychotics to patients with schizophrenia has been advised by national and/or international evidence-based practice guidelines for decades in the majority of countries $(1,2)$. However, implementation of the guidelines in clinical practice is still matter of concern. While there are positive examples of successful guideline implementation $(3,4)$, there are substantial barriers in many areas, especially in developing countries (5). The nature of these barriers is diverse, ranging from psychological to cultural, managerial and financial issues. Two hundred ninety-three potential barriers to guideline implementation were described and classified in the following groups: awareness of guidelines, familiarity with the guidelines, agreement with the guidelines, self-efficiency, outcome expectations, ability to overcome the inertia of previous practice, and external barriers to conduct recommendations (6).

The identification of all relevant barriers to the implementation of guidelines is an unavoidable step in the process of designing measures to improve antipsychotic prescribing in any region. Because the barriers are culture- and country-specific (7), only research in local settings could elucidate the main obstacles for employing these guidelines (8). In Montenegro, national treatment guidelines (9) for schizophrenia were issued just 2 years ago (in 2012), and their implementation was left to practitioners. There has been no research in Montenegro up to investigate the success of this effort.

The aim of our study was to estimate schizophrenia guideline adherence and identify eventual barriers to its implementation in Montenegro, using a focus group approach.

\section{MATERIALS AND METHODS}

This study used focus group methodology. The focus group was composed of two psychiatrists and one psychologist from a mixed secondary/tertiary care health facility in Podgorica, Montenegro, one pharmacist from a community pharmacy in Podgorica, one pharmacist from the State reimbursement fund of Montenegro, one pharmacist from a drug wholesaler in Podgorica and the chief investigator, a clinical pharmacologist. The group met on one occasion (June $17^{\text {th }}, 2013$ ) in a physicians' room at Psychiatric Clinic, Podgorica, Montenegro. The chief investigator prepared questions for the meeting (the guide) which he used as a tool for initiating discussion. The meeting had an informal brainstorming format without any schedule limitations for expressing opinions and attitudes. The duration of the meeting was 2 hours, and it was audio-recorded.

Over the following week, the investigators analysed the recordings independently and extracted emerging themes. They then held a new meeting where they achieved a consensus about the content and conclusions.
The framework approach was applied. Analysis was performed using an iterative qualitative technique and a constant comparison method. The thematic framework by which data were examined and referenced was drawn on "a priori issues" informed by the original research objectives and topics covered by the focus group guide as well as common sense categories anticipated during the process of data collection and transcribing.

As feedback validation, the investigators informed the focus group participants about the findings and conclusions, and they all agreed upon the remarks.

\section{RESULTS}

The barriers to implementation of national schizophrenia treatment guidelines that were identified by the focus group could be classified in the following theoretically informed categories: patient-related, prescriber-related, healthcare system-related and sociocultural issues.

\section{Patient-related barriers}

The participants of the focus group agreed that one of the most important patient-related barriers is low patient adherence to prescribed antipsychotic therapy. Although they said that "nobody is checking adherence of the patients to prescribed therapy", they believe that at "least $70 \%$ of the patients" were not taking their antipsychotics therapy as prescribed.

Another patient-related phenomenon could be their insufficient participation in decision-making process during prescribing. The psychiatrists said that they "...inform the patients completely, devoting a lot of manymuch time during their discharge to explaining everything about their therapy, and the patients sign documentation at the end that they are well-informed..." However, the psychiatrists also admitted that the patients with schizophrenia "...rarely take part in the prescribing decisions..."

\section{Prescriber-related barriers}

From the group discussion, it became clear that psychiatrists mostly avoid prescribing oral forms of atypical antipsychotics because "...the efficacy of risperidone and olanzapine is low in practice, although honorable professors keep saying that atypicals are very effective..." They said that atypicals "... are only helping $20-30 \%$ of patients and are suitable only for mild forms of schizophrenia..." Belief in the lack of effectiveness of risperidone and olanzapine is most likely the main reason psychiatrists avoid atypicals because because they were well-informed about and comfortable with the safety profiles. They stated, “... very frequently we observe hyperprolactinemia with risperidone, but this is easily handled by endocrinologists," and "...clozapine is effective drug, and its hematological adverse effects are rare...we check blood counts regularly..." 
The discussion revealed that only two atypical antipsychotics are usually prescribed (clozapine and risperidone).

The psychiatrists had long-term experience with typical antipsychotics and their efficiency and reliability in the moderate and severe forms of schizophrenia: “...when the patient is difficult, we give him haloperidol, and we calm him safely...if we give him risperidone, he just keeps on fooling around..." Although they agreed that a combination of antipsychotics is now given rarely ("...some retired doctors gave it to everybody in the past."), they "... still have to give it in difficult patients...when one antipsychotic is not enough..." The pharmacist from a community pharmacy said that she noticed "...the patients are oversedated... probablymost likely because of co-prescribed sedatives... but maybe for some other reason, I do not know...we have to ask psychiatrists..."

\section{Healthcare system-related barriers}

The availability of atypical antipsychotics is also an important factor which may influence underprescribing these pharmaceuticals. From the focus group discussions, it was determined that there is only one available option for the treatment of acute psychosis, i.e., only one parenteral immediate-release form of antipsychotics that has marketing authorisation in Montenegro: haloperidol, a typical antipsychotic. Moreover, although psychiatrists in Montenegro make prescribing decisions autonomously, prescribing newer atypical antipsychotics is a restricted procedure which requires endorsement by a special committee composed of three psychiatrists. Finally, although atypical antipsychotics are $100 \%$ covered by the Montenegrin State Reimbursement Fund, it frequently happens that they are not available in state-owned community pharmacies, so the patients have to buy them out-of-pocket.

Special problems in prescribing antipsychotics to patients with schizophrenia are made by certain organisational issues. The psychiatrists in secondary and tertiary care health facilities are obliged by local regulations to examine and treat any patient who on the premises, regardless of whether he or she was previously evaluated by general practitioner or primary care psychiatrist; a patient or accompanying person declaring a state of emergency necessitates medical attention. This puts a huge work burden on the hospital psychiatrists, and hampers their ability to consider various treatment options, including newer atypical antipsychotics.

\section{Sociocultural issues}

There was one clear sociocultural issue that emerged from the focus groups discussion: patients with schizophrenia are unable to completely understand their situation and therapy issues, as perceived by psychiatrists, their relatives, and professionals. The pharmacist from the community pharmacy said that "...mostly relatives of patients with schizophrenia come to pharmacies for drug refills...so it is difficult to explain things to the patients..." The psychiatrists said that "...they spend more time explaining things to the patient's relatives than to the patient themselves..."

\section{DISCUSSION}

The study showed that the issue of non-adherence to prescribed antipsychotic therapy is recognised by all group members. We classified it as a patient-related barrier, however, it might be more appropriate to evaluate this issue from different perspectives; because non-adherence is adversely interrelated with both healthcare professionals and system-related issues. The identified non-adherence issue might influence physicians' prescribing choices and attitudes toward of efficacy of new treatment options. According to views expressed by focus group participants, it is difficult to determine in clinical practice whether a patient is a non-responder or non-adherent to certain antipsychotic. Prescribers may switch to another antipsychotic with false impression that the previous one (e.g., atypical) was ineffective.

Non-adherence to medications in schizophrenia patients is well-acknowledged worldwide $(10,11)$. The landmark Clinical Antipsychotic Trials of Intervention Effectiveness (CATIE) study revealed that $74 \%$ of patients had discontinued their medication within 18 months (11). The World Health Organization identified non-adherence as most likely "the most challenging aspect" of multidisciplinary schizophrenia treatment (10).

Although evaluating the causes of non-adherence is beyond the scope of this study, there are some features declared by participants that are already identified as predictors of poor adherence in the literature (10). As it may be concluded both from the pharmacists' and psychiatrists' input, the patients' beliefs and attitudes are discounted in decisions about the therapy. In recent literature, concordance is consistently found to be a superior concept in addressing these issues rather than the traditional paternalistic doctor- patient relationship, where the prescribing regimen is not negotiated with patients themselves. (12)

On the other hand, there are some barriers unrelated to physicians which adversely affect guideline conformance and consequently treatment outcomes. Limited access to medicines was already identified as important barrier for guideline conformance (13). Our focus group also cited a lack of availability of the whole spectrum of pharmacological treatment options for schizophrenia both in hospital (only one parenteral antipsychotic for fast tranquilisation) and in the public pharmacy settings (more complicated procedure for getting atypicals prescribed, shortages of the atypicals in public pharmacies). In guideline-conformant schizophrenia treatment services it was found that "the absence of barriers to access for pharmacological therapies likely enhances the higher conformance to these (guideline) recommendations." (13). 
Although a patient-centered approach, a positive relationship with clinical staff at follow-up and guidance regarding drug use are found to be essential for improving adherence (10), there are system barriers that were identified and not addressed properly by the health authorities. Physicians emphasizised that time constraints adversely impact their capacity to provide appropriate care for their patients. The root of the problem might be traced to underuse of primary care psychiatric services and direct access to tertiary care psychiatrists for all those who think they urgently need psychiatrist.

In conclusion, the most important barriers to implementation of evidence-based guidelines for treatment of schizophrenia in Montenegro are non-adherence to medication, low level of psychiatrist-patient concordance, restrictive procedures for prescribing atypical antipsychotics, lack of availability of newer antipsychotics and some dosage forms, and mixing primary, secondary and tertiary care services within a tertiary care psychiatric institution. Addressing the barriers identified by this focus group and avoiding consequences of poor adherence would be the first steps for better mental health planning in the community.

\section{ACKNOWLEDGEMENTS}

This study was financially supported by a grant from the Ministry of Science, Montenegro.

\section{REFERENCES}

1. Gaebel W, Riesbeck M, Wobrock T. Schizophrenia guidelines across the world: a selective review and comparison. Int Rev Psychiatry 2011; 23(4): 379-87.

2. Hasan A, Wobrock T, Gaebel W, Janssen B, Zielasek J, Falkai P. National and international schizophrenia guidelines. Update 2013 regarding recommendations about antipsychotic pharmacotherapy]. Nervenarzt 2013; 84(11): 1359-60,1362-4, 1366-8.

3. Janssen B, Ludwig S, Eustermann H, Menke R, Haerter M, Berger M, Adam G, Seemann U, Kissling W, Gaebel W. Improving outpatient treatment in schizophrenia: effects of computerized guideline implementation-results of a multicenter-study within the German re- search network on schizophrenia. Eur Arch Psychiatry Clin Neurosci 2010; 260(1): 51-7.

4. Busch AB, Lehman AF, Goldman H, Frank RG. Changes over time and disparities inschizophrenia treatment quality. Med Care 2009; 47(2): 199-207.

5. Barbui C, Girlanda F, Ay E, Cipriani A, Becker T, Koesters M. Implementation of treatment guidelines for specialist mental health care. Cochrane Database Syst Rev 2014; 1: CD009780.

6. Cabana MD, Rand CS, Powe NR, Wu AW, Wilson MH, Abboud PA, Rubin HR. Why don't physicians follow clinical practice guidelines? A framework for improvement. JAMA 1999; 282(15): 1458-65.

7. Godlee F, Pakenham-Walsh N, Ncayiyana D, Cohen B, Packer A. Can we achieve health information for all by 2015? Lancet 2004; 364(9430): 295-300.

8. Larme AC, Pugh JA. Evidence-based guidelines meet the real world: the case of diabetes care. Diabetes Care 2001; 24(10): 1728-33.

9. Stevović-Injac L, Đedović J, Tomčuk A. Shizofrenija Nacionalne smjernice dobre kliničke prakse. Ministarstvo zdravlja, Radna grupa za izradu i implementaciju kliničkih protokola i smjernica i razvoj sistema osiguranja kvaliteta, Podgorica, 2012.

10. Higashi K, Medic G, Littlewood KJ, Diez T, Granström $\mathrm{O}$, De Hert M. Medication adherence in schizophrenia: factors influencing adherence and consequences of nonadherence, a systematic literature review. Ther Adv Psychopharmacol 2013; 3(4): 200-18.

11. Lieberman JA, Stroup TS, McEvoy JP, Swartz MS, Rosenheck RA, Perkins DO, Keefe RS, Davis SM, Davis CE, Lebowitz BD, Severe J, Hsiao JK; Clinical Antipsychotic Trials of Intervention effectiveness (CATIE) Investigators. Effectiveness of antipsychotic drugs in patients with chronic schizophrenia. N Engl J Med 2005; 353(12): 1209-23.

12. De las Cuevas C, Rivero-Santana A, Perestelo-Pérez L, Pérez-Ramos J, Serrano-Aguilar P. Attitudes toward concordance in psychiatry: a comparative, cross-sectional study of psychiatric patients and mental health professionals. BMC Psychiatry 2012; 12: 53.

13. Addington D, McKenzie E, Smith $H$, Chuang $H$, Boucher S, Adams B, Ismail Z. Conformance to evidence-based treatment recommendations in schizophrenia treatment services. Can J Psychiatry 2012; 57(5): 317-23. 